OPEN ACCESS

Edited by:

Cynthia B. Silveira,

San Diego State University,

United States

Reviewed by:

Michael S. Studivan,

Florida Atlantic University,

United States

Claudia Pogoreutz,

Universität Konstanz, Germany

*Correspondence:

Rachel M. Wright

rwright@smith.edu;

rachelwright8@gmail.com

Specialty section:

This article was submitted to

Coral Reef Research,

a section of the journal

Frontiers in Marine Science

Received: 15 July 2019

Accepted: 16 October 2019 Published: 05 November 2019

Citation:

Wright RM, Correa AMS, Quigley LA, Santiago-Vázquez LZ, Shamberger KEF and Davies SW

(2019) Gene Expression

of Endangered Coral (Orbicella spp.) in Flower Garden Banks National

Marine Sanctuary After Hurricane Harvey. Front. Mar. Sci. 6:672. doi: 10.3389/fmars.2019.00672

\section{Gene Expression of Endangered Coral (Orbicella spp.) in Flower Garden Banks National Marine Sanctuary After Hurricane Harvey}

\author{
Rachel M. Wright ${ }^{1,2,3 *}$, Adrienne M. S. Correa ${ }^{4}$, Lucinda A. Quigley', \\ Lory Z. Santiago-Vázquez ${ }^{5}$, Kathryn E. F. Shamberger ${ }^{6}$ and Sarah W. Davies ${ }^{1}$
}

${ }^{1}$ Biology Department, Boston University, Boston, MA, United States, ${ }^{2}$ Genetics Department, Harvard Medical School, Boston, MA, United States, ${ }^{3}$ Department of Biological Sciences, Smith College, Northampton, MA, United States, ${ }^{4}$ BioSciences at Rice, Rice University, Houston, TX, United States, ${ }^{5}$ Department of Biology and Biotechnology, University of Houston-Clear Lake, Houston, TX, United States, ${ }^{6}$ Department of Oceanography, Texas A\&M University, College Station, TX, United States

About $190 \mathrm{~km}$ south of the Texas-Louisiana border, the East and West Flower Garden Banks (FGB) have maintained > 50\% coral cover with infrequent and minor incidents of disease or bleaching since monitoring began in the 1970s. However, a mortality event, affecting 5.6 ha (2.6\% of the area) of the East FGB, occurred in late July 2016 and coincided with storm-generated freshwater runoff extending offshore and over the reef system. To capture the immediate effects of storm-driven freshwater runoff on coral and symbiont physiology, we leveraged the heavy rainfall associated with Hurricane Harvey in late August 2017 by sampling FGB corals at two time points: September 2017, when surface water salinity was reduced ( 34 ppt); and 1 month later when salinity had returned to typical levels ( 36 ppt in October 2017). Tissue samples $(N=47)$ collected midday were immediately preserved for gene expression profiling from two congeneric coral species (Orbicella faveolata and Orbicella franksi) from the East and West FGB to determine the physiological consequences of stormderived runoff. In the coral, differences between host species and sampling time points accounted for the majority of differentially expressed genes. Gene ontology enrichment for genes differentially expressed immediately after Hurricane Harvey indicated increases in cellular oxidative stress responses. Although tissue loss was not observed on FGB reefs following Hurricane Harvey, our results suggest that poor water quality following this storm caused FGB corals to experience sub-lethal stress. We also found dramatic expression differences across sampling time points in the coral's algal symbiont, Breviolum minutum. Some of these differentially expressed genes may be involved in the symbionts' response to changing environments, including a group of differentially expressed post-transcriptional RNA modification genes. In this study, we cannot disentangle the effects of reduced salinity from the collection time point, so 
these expression patterns could also be related to seasonality. These findings highlight the urgent need for continued monitoring of these reef systems to establish a baseline for gene expression of healthy corals in the FGB system across seasons, as well as the need for integrated solutions to manage stormwater runoff in the Gulf of Mexico.

Keywords: coral reef, Flower Garden Banks (FGB) National Marine Sanctuary, Orbicella faveolata, Orbicella franksi, gene expression, Hurricane Harvey

\section{INTRODUCTION}

Reef-building corals are among the tropical marine species most vulnerable to the effects of hurricanes (Woodley et al., 1981; Gardner et al., 2005). Coral colonies can be impacted by hurricanes via physical damage from waves, smothering by sediments (Highsmith et al., 1980; Bries et al., 2004), and reductions in water quality (e.g., Manzello et al., 2013; Edmunds, 2019; Nelson and Altieri, 2019). Low salinity caused by heavy rainfall associated with extreme storms can trigger mass loss of the algal endosymbionts of corals (Family Symbiodiniaceae, Goreau, 1964; Bries et al., 2004; LaJeunesse et al., 2018; Pengsakun et al., 2019). Increased turbidity due to terrestrial runoff during storms can significantly reduce light penetration over reefs, which diminishes the algal symbionts' photosynthetic efficiencies. For example, Hurricanes Irma and Maria caused temporary periods of complete daytime darkness at a depth of $19 \mathrm{~m}$ on a reef off St. John in the US Virgin Islands in 2017 (Edmunds, 2019). As a result, these storms caused a $20 \%$ reduction in daily integrated underwater photosynthetic photon flux density over a period of 69 days. Coral calcification can be directly impacted by reduced water quality following hurricanes. For example, Tropical Storm Isaac in 2012 caused a week-long reduction in aragonite saturation state along the Florida Keys reef tract, which could potentially cause a decrease in coral calcification (Manzello et al., 2013). Terrestrial runoff following extreme storms can increase nutrient levels in these normally oligotrophic reef-associated waters, causing bacterial blooms that can ultimately trigger oxygen drawdown and suffocation of reef organisms (e.g., Kealoha, 2019; Nelson and Altieri, 2019). An overview of the diverse mechanisms by which shifts in water quality can trigger low dissolved oxygen conditions is provided in Nelson and Altieri (2019).

Flower Garden Banks (FGB) National Marine Sanctuary, in the northwest Gulf of Mexico, which harbors one of the few remaining reef systems in the wider Caribbean with $>50 \%$ coral cover (Gardner et al., 2003; Johnston et al., 2016), sits southeast of Galveston Bay and thus is at risk of exposure to terrestrial freshwater runoff generated by hurricanes. Hurricane Harvey, the focal storm of this study, intensified to a Category 4 storm over the Gulf of Mexico on 24 August 2017 and made landfall on the Texas coast shortly after. The storm stalled over land for several days, resulting in an estimated 33 trillion gallons of rainfall and more than 100,000 damaged homes in Texas and Louisiana (Shultz and Galea, 2017; van Oldenborgh et al., 2017). In the weeks following the storm's retreat, Galveston Bay experienced heavy freshwater outflow, that elevated sea levels for more than four days and reduced salinity to nearly zero at multiple monitoring stations in the bay (Du et al., 2019). Besides being hyposaline, this storm-derived runoff contained high nutrients levels and other compounds of terrigenous origin, that had the potential to shift pelagic bacterial and zooplankton communities and their associated processes (Lefebure et al., 2013; Jonsson et al., 2017), and to impact the health of organisms that came in contact with the runoff (Liñán-Cabello et al., 2016).

While Hurricane Harvey did not cause direct physical damage to FGB coral reefs, impacts from the storm runoff were of particular concern given that approximately 1 year earlier (July 2016) benthic invertebrates in a 5.6 ha area $(2.6 \%$ of the site) of the East FGB experienced a highly localized mortality event that was associated with freshwater runoff. The 2016 mortality event caused partial or full mortality of an estimated $82 \%$ of monitored coral colonies, as well as many other benthic invertebrates, within the affected area (Johnston et al., 2019). While no water quality data were collected near the coral cap at the mortality site during the 2016 die-off, surface and deep (200 m) salinity, temperature, and carbonate chemistry measurements collected from the area soon after the event suggest low dissolved oxygen played a critical role (Kealoha, 2019). Heavy rainfall along the coast immediately before the 2016 mortality event resulted in unusually high levels of freshwater runoff. This runoff extended offshore to the FGB but was restricted to a thin surface layer that did not directly interact with the reefs, however, it likely contributed to an increase in net respiration on the reef, water stratification, and reduced gas exchange at the affected site (Kealoha, 2019). Given the FGB's recent history of coral mortality following high levels of freshwater runoff, the aim of this study was to identify the immediate physiological impacts of a major storm (Hurricane Harvey in 2017) in the same reef system: the East and West FGB. Two congeneric coral species (Orbicella faveolata and Orbicella franksi) were sampled at two time points: immediately after Hurricane Harvey in September 2017 and 1 month later. Global gene expression profiling of these corals and their photosynthetic algal symbionts (Breviolum minutum) was conducted to determine the physiological consequences of runoff generated by an extreme storm on dominant reef-building coral species in the FGB.

\section{MATERIALS AND METHODS}

\section{Pelagic Water Properties After Hurricane Harvey}

Water properties, including salinity (ppt) and temperature $\left({ }^{\circ} \mathrm{C}\right)$, were measured by the Texas Automated Buoy System 
(TABS) Real Time Ocean Observations, Buoy V $\left(27^{\circ} 53.7960^{\prime} \mathrm{N}\right.$, $93^{\circ} 35.8380^{\prime} \mathrm{W}$; sensor depth $2 \mathrm{~m}$ ), before, during, and after coral sampling. Buoy $\mathrm{V}$ is approximately $3 \mathrm{~km}$ from the EFGB and $25 \mathrm{~km}$ from the WFGB. Data were downloaded from the archives: http://tabs.gerg.tamu.edu/tglo/tabsqueryform.php? buoy $=\mathrm{V}$. Unfortunately, water property data at TABS Buoy V do not exist for much of August 2017, including when Hurricane Harvey formed over the Gulf of Mexico (approximately 25 August 2017). Surface salinity and temperature were reduced in the days prior to the September coral collection (red lines in Figure 1), presumably due to anomalous freshwater runoff effects from the storm. Surface salinity returned to normal levels by the second collection time point (October 2017; Figure 1 top right dashed line). Henceforth, we refer to the first sampling time point (September 2017) as "sub-lethal stress" and the second sampling time point (October 2017) as "recovery" to describe the hypothesized effects of the storm on the coral and its algal symbiont at those times.

\section{Coral Collections}

Tissue fragments were collected from individually tagged O. faveolata and O. franksi coral colonies in FGB (northwest Gulf of Mexico) during periods of "sub-lethal stress" (on 16 September 2017, EFGB only) and "recovery" (October 21-24, 2017, East and West Banks, Supplementary Table 1). In total, 23 samples of $O$. faveolata and 24 samples of $O$. franksi were collected over the two sampling periods (Table $\mathbf{1}$ ).

The depths of sampled colonies ranged from 19.2 to $24.1 \mathrm{~m}$. Details on the locations and depths of samples collected for each coral species are provided in Supplementary Table 1. Samples were collected from the tops of colonies using a hammer and a species-specific chisel and were immediately placed in pre-labeled upside-down $15 \mathrm{~mL}$ falcon tubes containing 200 proof molecular grade $\mathrm{EtOH}$ free of air bubbles.

\section{Gene Expression Library Preparation}

RNA was isolated from 47 coral tissue samples using the RNAqueous-Micro Total RNA Isolation Kit (Invitrogen). Coral fragments $\left(\sim 1 \mathrm{~cm}^{2}\right.$ tissue) were fully submerged in tubes containing $150 \mu \mathrm{L}$ of lysis buffer and glass beads (Sigma, $150-212 \mu \mathrm{m})$. Samples were placed in a bead blaster at $5 \mathrm{~m} / \mathrm{s}$ for $1 \mathrm{~min}$ and then centrifuged at a speed of $16.5 \times \mathrm{g}$ for $1 \mathrm{~min}$. The supernatant was transferred to a new tube and centrifuged again at $16.5 \times \mathrm{g}$ for $2 \mathrm{~min}$, and then transferred to a final tube. RNA was eluted, washed, and DNased using $10 \times$ DNase I. Firststrand synthesis, cDNA amplification, barcoding, and pooling were performed according to an established protocol (Meyer et al., 2011; Dixon et al., 2015). We used a polyT primer to enrich for polyadenylated mRNA during first-strand synthesis. A total of 47 gene expression libraries were prepared in-house following the Tag-Seq protocol mentioned above (Meyer et al., 2011), with 20 from September 2017 and 27 from October 2017. Libraries were sequenced on the HiSeq 2500 (Illumina) at Tufts University Core Facility (Boston, MA). Sequenced reads have been uploaded to the National Center for Biotechnology Information Short Read Archive under accession number PRJNA552981.

\section{Gene Expression Analysis}

Adapter sequences were trimmed and low quality reads (minimum quality score $=20$; minimum percent bases above

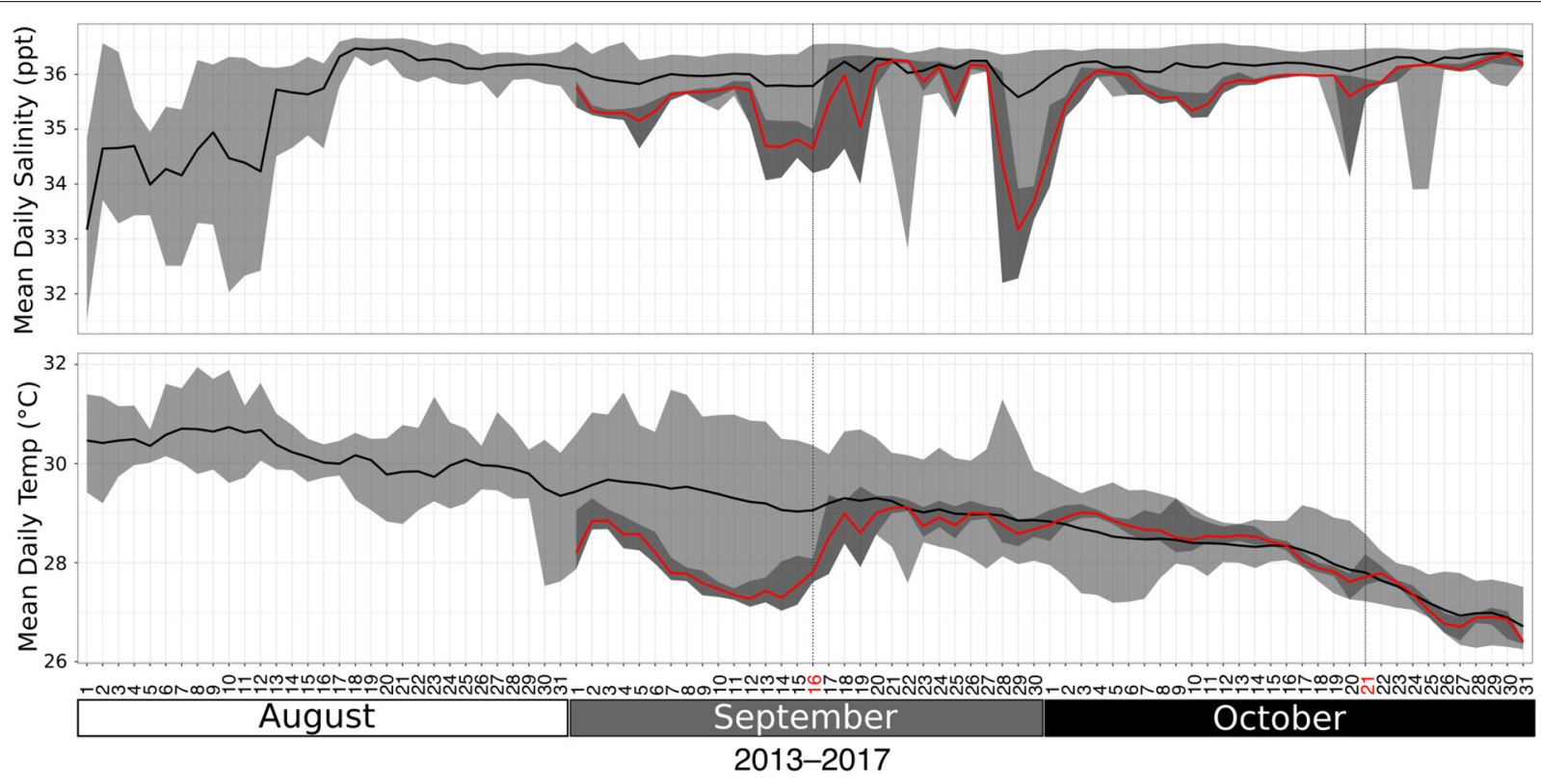

FIGURE 1 | Salinity (ppt, top) and temperature $\left({ }^{\circ} \mathrm{C}\right.$, bottom) at buoy $\vee$ near the coral sampling sites at the East and West Flower Garden Banks for the weeks surrounding the time of sampling. Black lines represent daily means from 2013-2017. Light gray ribbons encompass minimum and maximum values from 2013-2017. Red lines and dark gray ribbons encompass daily means and ranges, respectively, throughout September 2017 and October 2017 . Dates in red (16 September and 21 October, vertical dashed lines) highlight the sampling days in 2017. 
TABLE 1 | Overview by species, location, and time of the 47 coral colonies sampled from the East and West Banks of Flower Garden Banks National Marine Sanctuary (northwest Gulf of Mexico) in this study.

\begin{tabular}{lccc}
\hline & East FGB & West FGB & Total \\
\hline $\begin{array}{lccl}\text { Orbicella faveolata } \\
\text { September 2017 }\end{array}$ & 10 & 0 & 10 \\
October 2017 & 6 & 7 & 13 \\
Total & 16 & 7 & 23 \\
Orbicella franksi & & 0 & \\
September 2017 & 10 & 8 & 10 \\
October 2017 & 6 & 8 & 14 \\
Total & 16 & & 24 \\
\hline
\end{tabular}

minimum quality score $=90 \%$ ) were filtered using FASTX tools (Hannon, 2010). Reads were mapped to a composite coral host and algal symbiont transcriptome, which included concatenated sequences from the coral, O. faveolata (Pinzon et al., 2015), and its algal symbiont, B. minutum (Parkinson et al., 2016), using Bowtie 2 (Langmead and Salzberg, 2012). Given that only B. minutum and its haplotypes have been reported from O. faveolata and O. franksi in the FGB to date (Santos and LaJeunesse, 2006; Green et al., 2014), this species was the only algal reference transcriptome used. Statistical analyses were conducted in $\mathrm{R}$ version 3.4.0 (R Core Team, 2017). Isogroups (henceforth called "genes") with a base mean $<3$ across all samples were removed from the analysis. Expression sample outliers were detected using arrayQualityMetrics (Kauffmann et al., 2009). Differentially expressed genes (DEGs) were identified using DESeq2 (Love et al., 2014). Wald tests were performed to calculate contrasts between sampling time points, host species, and collection location (i.e., EFGB or WFGB). Additionally, we performed Wald tests on the subset of samples from only the second collection to further investigate site effects. Log-fold change (LFC) values for sampling time point are expressed relative to the October collection (e.g., negative LFC indicates upregulation in September relative to October or, equivalently, downregulation in October relative to September). False-discovery rate (FDR) $p$-values were adjusted using the Benjamini-Hochberg procedure (Benjamini and Hochberg, 1995). Permutational analysis of variance testing on Manhattan dissimilarity matrices was performed using vegan (Dixon, 2003) to assess overall transcriptomic differences across samples. Gene expression heat maps were generated using pheatmaps (Kolde, 2012) and gene ontology enrichment was performed based on signed adjusted $p$-values using GO-MWU (Wright et al., 2015).

\section{RESULTS}

\section{Gene Expression Associated With Coral Host, Sampling Time Point, and Collection Site}

An average of $1.85 \times 10^{6}$ host reads per sample and $0.2 \times 10^{6}$ symbiont reads per sample remained after quality filtering and mapping to the $O$. faveolata and B. minutum transcriptomes. Both coral host species were mapped to the $O$. faveolata transcriptome, but we observed no significant difference in mapping efficiency between O. faveolata $(50.7 \pm 7.9 \%)$ and O. franksi (47.0 $\pm 10.3 \%$, analysis of variance [ANOVA] $p=0.179$, $F=1.9)$. In the coral host, differences between Orbicella species (analysis of variance using a distance matrix [ADONIS] $p=0.008$, $F=2.3$ ) and sampling time points (ADONIS $p=0.026$, $F=2.0$ ) explain the majority of the observed differences in gene expression profiles (Figure 2A). There was no significant variance in host gene expression associated with sampling locations

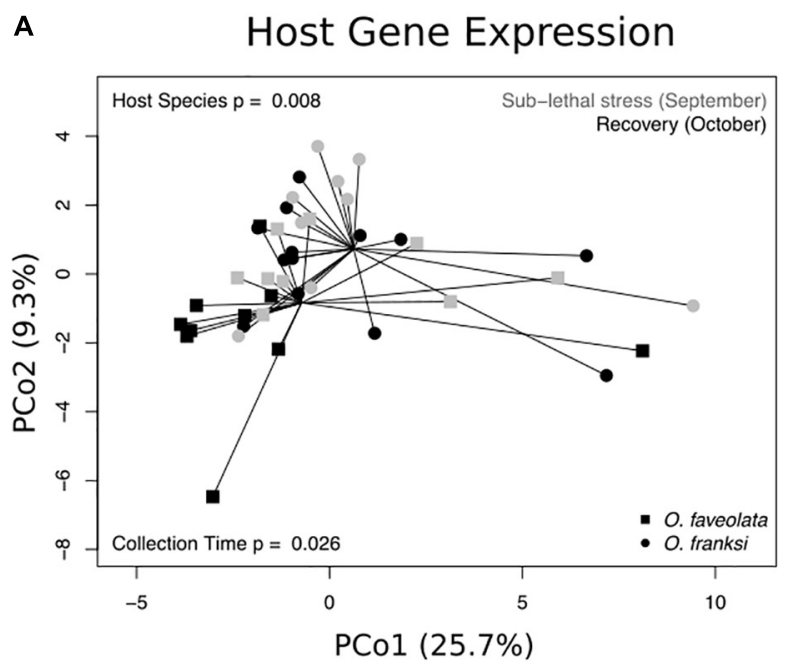

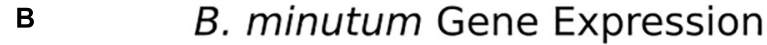

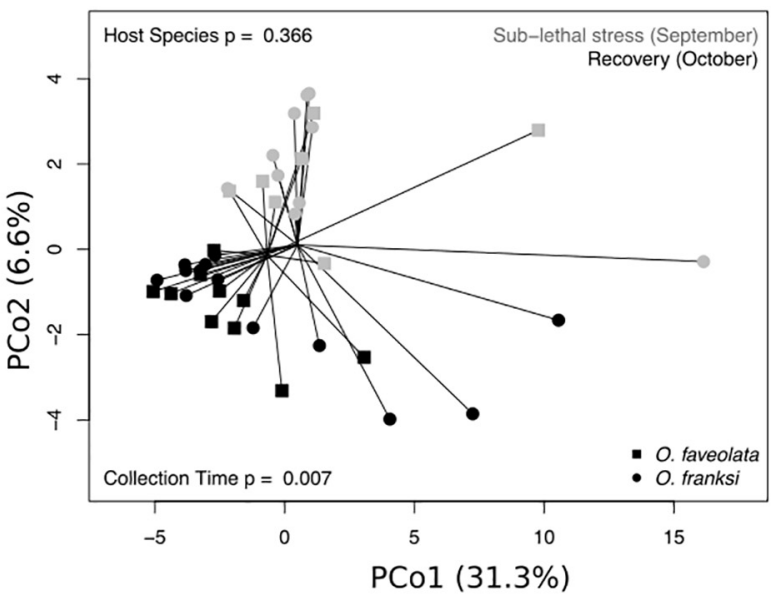

FIGURE 2 | Principal coordinates analysis for coral host (A) and B. minutum (B) gene expression profiles. Each point is a sample and points closer together exhibit more similar expression profiles. Spider lines connect samples originating from the same coral species (Orbicella faveolata or Orbicella franksi), as indicated. Colors indicate whether the sample was collected during the sub-lethal stress (September, gray) or recovery (October, black) period. $P$-values were generated by permutational multivariate analysis of variance using distance matrices. 
(ADONIS $p=0.063, F=0.037$ ). B. minutum expression profiles were impacted by sampling time point (ADONIS $p=0.007$, $F=3.1$ ), but not host species (ADONIS $p=0.366, F=0.99$ ) or sampling location (ADONIS $p=0.125, F=1.4$ ) (Figure 2B).

We used an adjusted $p$-value threshold of 0.05 calculated by the Wald test to identify significantly differentially expressed genes (DEGs) in the coral host (Figure 3A) and algal symbiont, B. minutum (Figure 3B). In the coral host, we identified 769 (3.9\% of transcriptome) and 265 (1.3\% of transcriptome) DEGs when comparing between species (O. faveolata vs. O. franksi) and time (September sublethal stress vs. October recovery), respectively. Fifteen genes were significantly differentially expressed between the EFGB and WFGB sampling locations in the coral host $(0.08 \%$ of transcriptome). In B. minutum, we identified $1,471 \quad(4.6 \%$ of transcriptome) and $21(0.07 \%$ of transcriptome) DEGs when comparing between time (September sub-lethal stress vs. October recovery) and sampling location (EFGB vs. WFGB), respectively. We found only two DEGs when comparing B. minutum expression between the two coral host species $(<0.01 \%$ of transcriptome).

When we performed differential expression analysis to model differences by coral species and site on a subset of the data (second time point only; first time point excluded because data for WFGB were not available), we still found little differential expression between site. Only one gene was differentially expressed across coral hosts between EFGB and WFGB, and 13 DEGs were identified between algal symbionts from different banks.

\section{Gene Ontology Enrichment}

In the coral host, gene ontology (GO) categories enriched during the sub-lethal low salinity stress event (September 2017) included antioxidant activity (Mann-Whitney $U$ [MWU] $p=0.013$ ), cell redox homeostasis (MWU $p=0.039$ ), and mitochondrial membrane parts (MWU $p=4.04 \mathrm{e}-7$ ) (Supplementary Table 2). When normal salinity levels had returned, during the "recovery" time point, many categories related to growth and cellular propagation were enriched within up-regulated genes, such as cell division (MWU $p=0.003$ ) and organelle fission (MWU $p=0.003)$. No GO terms were significantly enriched when comparing genes differentially expressed by either host species or sampling location.

The annotated coral host genes differentially regulated across the sub-lethal stress and recovery periods are shown in Figure 4. Relative to the recovery period, corals under sublethal low salinity stress up-regulated small cysteine rich protein $4(\mathrm{LFC}=-3.48, \mathrm{FDR}=4.2 \mathrm{e}-8)$ and down-regulated protein WNT-5 $(\mathrm{LFC}=1.76, \mathrm{FDR}=0.006)$.

In the algal symbiont, $B$. minutum, enriched GO categories under sub-lethal low salinity stress conditions (September 2017) included oxidoreductase activity $(p=0.03)$ and transmembrane transport ( $p=2.76 \mathrm{e}-5$ ) (Supplementary Table 3 ). When average salinity levels had returned in October 2017 (i.e., during "recovery"), many GO categories related to DNA replication and RNA splicing were enriched with up-regulated genes (Supplementary Table 3). RNA splicing was also enriched in algal symbionts hosted by $O$. faveolata relative to algal symbionts hosted by O. franksi (Supplementary Table 3).

In $B$. minutum, the majority of significant DEGs were upregulated during the recovery period (October 2017) or, equivalently, downregulated during the sub-lethal salinity stress event in September 2017 (Figure 5). These genes include an RNA helicase $(\mathrm{LFC}=2.0, \mathrm{FDR}=4.85 \mathrm{e}-5)$ and a nonsense-mediated mRNA decay protein $(\mathrm{LFC}=1.5, \mathrm{FDR}=1.80 \mathrm{e}-5)$.

\section{DISCUSSION}

\section{Transcriptomic Effects of Freshwater From Hurricane Harvey on Coral Holobionts}

The objective of this study was to use global gene expression profiling to determine the effects of a low salinity event associated with freshwater from Hurricane Harvey on two species of coral hosts and their algal symbionts in the FGB (northwest Gulf of Mexico). Based on differences in pelagic water parameter data and coral holobiont gene expression differences between the two sampled time periods, we interpret that FGB coral and their symbionts were exhibiting early signs of stress as a result

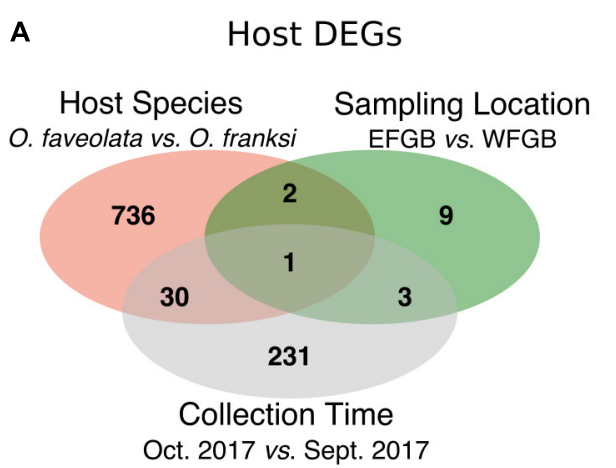

B Breviolum minutum DEGs

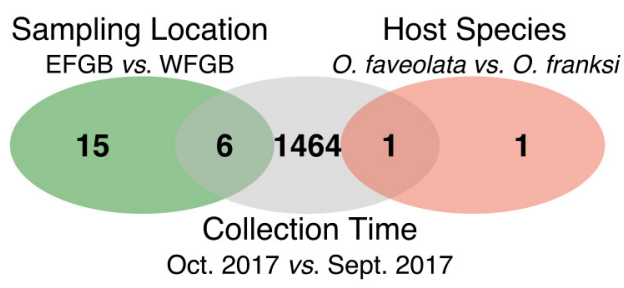

FIGURE 3 | Venn-diagrams specifying the number of unique and shared differentially expressed genes (adjusted $p$-value < 0.05) by Orbicella host species, sampling location, and collection time point (September sub-lethal stress and October recovery) in the coral hosts (A) and Breviolum minutum (B). 


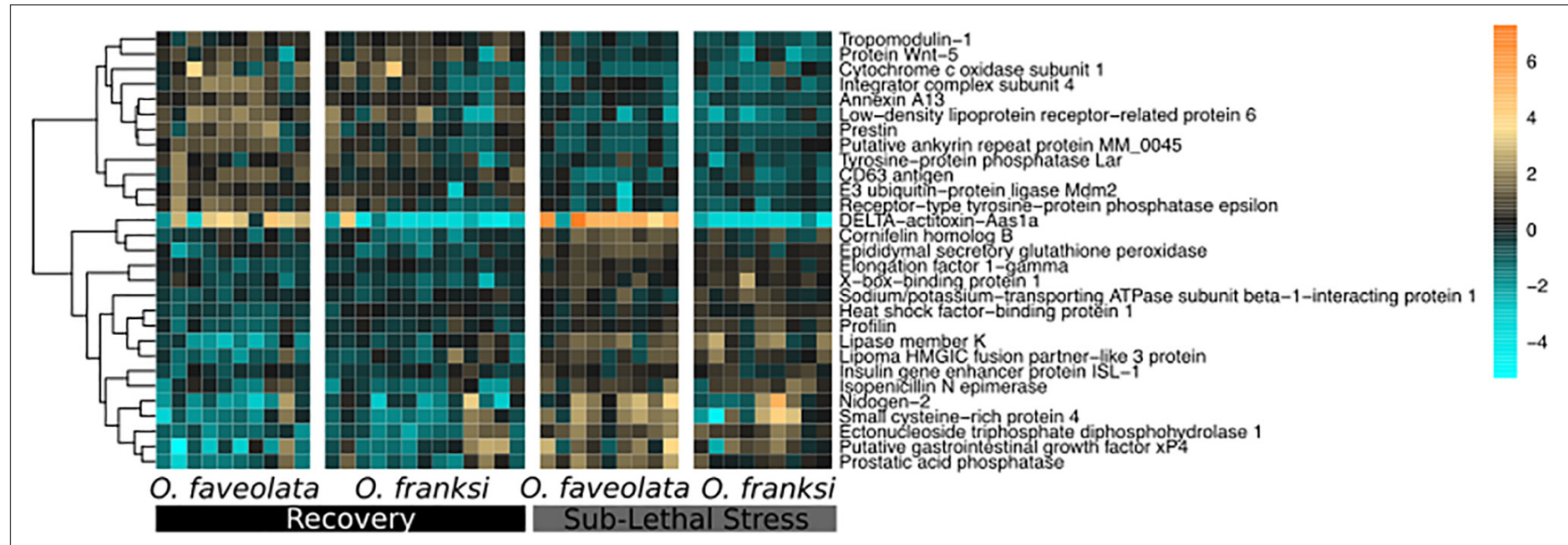

FIGURE 4 | Orbicella spp. host gene expression differences across collection time points: sub-lethal stress vs. recovery (September 2017 vs. October 2017 , FDR < 0.01). Rows are genes and columns are samples. The color scale indicates log2-fold change relative to the mean expression of each gene across all samples. Genes are hierarchically clustered based on Pearson's correlations of expression across samples. Coral species are indicated below each column. Rectangles below coral species labels indicate the collection time point (black = October 2017 recovery; gray = September 2017 sub-lethal stress).
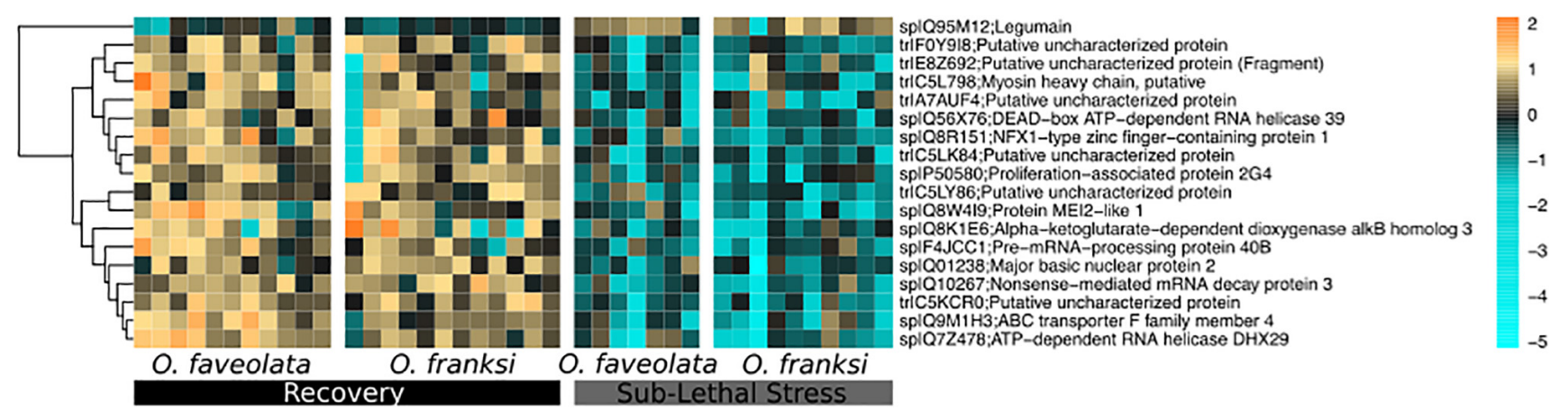

FIGURE 5 | Breviolum minutum gene expression differences across sampling time: sub-lethal stress vs. recovery (September 2017 vs. October 2017 , FDR < 0.0001). Rows are genes and columns are samples. The color scale indicates log2-fold change relative to the mean expression of each gene across all samples. Genes are hierarchically clustered based on Pearson's correlations of expression across samples. Coral species are indicated below each column. Rectangles below coral species labels indicate the collection time point (black = October 2017 recovery; gray = September 2017 sub-lethal stress.

of freshwater runoff in September 2017, but that the influence of this freshwater influx was alleviated (i.e., recovered) by late October 2017. Conditions at the time of collection did not allow a complete sampling scheme that included individuals from each at both time points. We accounted for differences in expression by site by including sampling location as a covariate in the statistical model. Additionally, we ran differential expression analysis on a subset of the data that included both species from the East and West FGB. In either instance, we observed fewer than 30 genes differentially expressed across sites from either the coral host or algal symbiont compared with hundreds of DEGs by coral species or collection time point, suggesting that sampling location had a minimal effect on holobiont expression.

The TABS buoy that provided salinity data used in this analysis measured salinity near the surface and thus may not represent salinity experienced at depth (19-24 m for corals observed in this study). The analysis for contributing causes of coral mortality from the 2016 mortality event also rely on observations of reduced surface salinity (minimum 23 ppt; Johnston et al., 2019). While we cannot confirm saline conditions experienced by the corals at depth during the 2016 mortality event or after Hurricane Harvey in 2017, this study adds to mounting evidence that hyposaline surface conditions contribute to stress in benthic organisms.

\section{Oxidative Stress in the Coral Host}

Corals are osmoconformers: when exposed to hyposaline conditions, water flows into their cells, thereby reducing internal cellular osmotic pressure (Titlyanov et al., 2000). The amount of damage cells sustain under reduced salinity depends on the extent of this osmotic pressure reduction and the length of time that cells are exposed to the stress (Berkelmans et al., 2012). Stylophora pistillata fragments exposed to five salinity concentrations ranging from 20-32 ppt showed increasingly severe cellular pathologies, including cell swelling and symbiont expulsion, with decreasing salinity (Downs et al., 2009). Within 
the coral cell, osmotic changes disrupt electron transport at mitochondrial membranes and increase reactive oxygen species produced by mitochondria. Consequently, robust mitochondrial antioxidant function is thought to be a major determinant of cellular management of osmotic stress (Pastor et al., 2009).

In both coral host species, GO categories were enriched with genes involved in antioxidant activity and mitochondrial structural components, suggesting the presence of oxidative damage that may compromise mitochondrial function (Supplementary Table 2). A recent experimental study in Acropora millepora, a reef-building coral in the Great Barrier Reef, also found a strong antioxidant response to reduced salinity (Aguilar et al., 2019), suggesting that this response mechanism is conserved across coral genera. The upregulation of antioxidantencoding genes has been described in corals exposed to a variety of biotic and abiotic threats, including increased temperature (Barshis et al., 2013; Dixon et al., 2015), acidification (Davies et al., 2016; Lopes et al., 2018), and disease (Wright et al., 2015, 2017; Daniels et al., 2015).

Given the diversity of stressors that trigger redox responses in corals, sub-lethal oxidative damage resulting from one stressor may contribute to coral declines when multiple threats occur simultaneously or successively (Adjeroud et al., 2009; Carilli et al., 2009). This study adds to the large body of evidence that genetic markers for antioxidant capability may be useful reef management tools to monitor coral health in the face of multiple climate change-related stressors (Jin et al., 2016).

\section{Expression Responses in B. minutum}

At the FGB, both Orbicella species investigated here have been found to exclusively host B. minutum (Santos and LaJeunesse, 2006; Green et al., 2014), although subtle haplotype differences within B. minutum have been detected between these two host species as well as between the East and West FGB (Green et al., 2014). When comparing gene expression of the algal symbiont, we found only one $B$. minutum gene uniquely differentially expressed between coral hosts and 15 B. minutum DEGs between sampling locations (Figures 3B, 5). In B. minutum, collection time point had the strongest association with the observed variance in gene expression (Figure 2B).

This gene expression response is in contrast to previous studies investigating the effects of multiple stressors on algal symbiont gene expression, which generally detect a paucity of expression changes and these changes are muted relative to their coral hosts (Leggat et al., 2011; Barshis et al., 2014; Davies et al., 2018, but see Baumgarten et al., 2013). One potential explanation is that we sampled before host buffering or acclimatization mechanisms diminished the symbiont response (e.g., Takahashi et al., 2013; Maboloc et al., 2015). Furthermore, our findings may be influenced by additive or interactive effects between poststorm water quality metrics and seasonal fluctuations (Brown et al., 1999), which have not been explicitly characterized in Symbiodiniaceae in hospite to our knowledge.

A major category of genes differentially expressed in B. minutum across time points is associated with RNA-modification (Supplementary Table 3; Figure 5). These candidates include a gene encoding a nonsense-mediated
RNA decay protein $(\mathrm{LFC}=1.5, \mathrm{FDR}=1.8 \mathrm{e}-5$; Figure 5) and a gene encoding Regulator of Nonsense Transcripts 1 homolog (sp| Q9HEH1, LFC = 1.7, FDR = 0.03), which were both downregulated in September 2017 during the storm-induced low salinity period. In plants and mammals, nonsense-mediated decay (NMD) is inhibited during stress to allow proper activation of stress response functions. For example, inhibition of NMD under hypoxia augments the cellular stress response in mammalian cells (Gardner, 2008) and inhibition of NMD in plant cells under pathogen attack stimulates plant defenses (reviewed in Shaul, 2015). In our study, the downregulation of NMD-related genes may indicate symbiont stress sustained as a result of hyposalinity. Furthermore, a gene encoding Regulator of Nonsense Transcripts 1 homolog was also found to be differentially expressed in another coral symbiont, Durusdinium (formerly Symbiodinium) trenchii, within a juvenile Acropora tenuis host under benign conditions (Yuyama et al., 2018), suggesting that the gene product may play a role in normal interactions between the coral host and algal symbiont.

While these gene expression differences may be responses to the sub-lethal low salinity stress event associated with Hurricane Harvey experienced in September 2017, we also cannot disentangle responses to this event from seasonal changes occurring between the sampling time points, which would include lower light levels associated with slightly shorter and cooler days on average (Figure 1). Based on previous experimental studies conducted in other systems, the salinities observed at FGB in September 2017 may not have been low enough to trigger a response in the symbiont. Experimental exposures to low salinity (15-33.5 ppt) in S. pistillata caused symbiont loss coincident with reductions in photosynthetic efficiency (Kerswell and Jones, 2003). However, in that experiment, salinities above 29 ppt failed to elicit an algal response. In another experiment, Symbiodiniaceae hosted by juvenile Tridacna gigas (giant clam) exhibited cell swelling, degradation, and pigment reductions at $18 \mathrm{ppt}$ for 14 days, but algal cells within the clams were able to acclimatize to reduced salinity at 25 ppt (Maboloc et al., 2015). Thus, tankbased salinity stress experiments on Orbicella spp. holobionts from FGB can further confirm (or undermine) the conclusion that reduced salinity caused the gene expression changes we observed in B. minutum in the September 2017 samples. Regardless, our results inform our broader understanding of when and to what extent algal symbionts respond to changing environments and hosts.

\section{Transcriptomic Differences Between Orbicella Species}

In the animal host, differences between congeneric coral species explained the most variation in expression (Figures 2, 3A). Coral transcripts from both species represented in this study were mapped to the $O$. faveolata transcriptome and both species had similar mapping efficiencies to this reference. Previously classified as sister species within the genus Montastraea, Orbicella faveolata, and O. franksi are largely 
sympatric (Weil and Knowlton, 1994) and have many shared physical attributes that make them difficult to distinguish morphologically, though genetic variant analysis can resolve each species (Manzello et al., 2018). Differential gene expression between the two species that occurs independently of the effects of Hurricane Harvey are not the focus of this study, but do deserve consideration. The sequence datasets generated here can contribute to further research into species-specific coral expression, which, to our knowledge, has not been directly compared in these species. The top DEG between the two coral species shares substantial homology with an anemone (Anthopleura asiatica) toxin: DELTA-actitoxin-Aas1a (Kohno et al., 2009). This transcript, which was much more highly expressed in O. faveolata $(\mathrm{LFC}=7.44, \mathrm{FDR}=3.98 \mathrm{e}-22)$, may indicate species-specific toxins that have yet to be characterized in these corals. We did not find any enriched GO categories between these coral species.

In $B$. minutum, coral host species had almost no effect on gene expression (Figures 2, 3B). The one transcript that was differentially regulated between the two host species $(\mathrm{LFC}=2.18$, $\mathrm{FDR}=1.03 \mathrm{e}-6)$ was unannotated in the transcriptome but shares sequence homology with an S-antigen protein (identity $=40.9 \%$, $E$-value $=7.9 \mathrm{e}-68)$. Characterization of this protein is largely limited to variants associated with immune reactions in humans (e.g., Nussenblatt et al., 1982). Given the importance of host immune activation during the establishment and maintenance of symbiosis in corals (Mansfield et al., 2019) and the fact that these species have been found to host subtly different symbiont populations (Green et al., 2014), this differentially regulated transcript with antigenic potential deserves further investigation for its potential role in host-symbiont recognition.

\section{Implications for Impacts of Future Storms on Reefs}

The water surge that completely reduced salinity within Galveston Bay during Hurricane Harvey (Du et al., 2019) did not reduce salinity beyond levels observed in the past 5 years at FGB (Figure 1), probably because the water mass did not pass directly over the reef itself. Fortunately, the coral holobionts observed in this study were not exposed to extreme hyposalinity and the salinity reduction that did occur was quickly alleviated. Sustained reductions in salinity can result in mass coral mortality. In 1963, Hurricane Flora reduced coral reef salinity on several reefs in Eastern Jamaica to 3 ppt days after the storm and the region remained below $30 \mathrm{ppt}$ for more than 5 weeks (Goreau, 1964). As a result, multiple genera of corals in the region experienced substantial coral bleaching, though many colonies recovered fully within a few months. In 1987, heavy rains in Kaneohe Bay, Hawaii substantially reduced salinity and caused mass coral mortality (Jokiel et al., 1993). Some species of corals (e.g., Porites compressa) in Kaneohe Bay recovered well, and comparisons to past mortality events support the ability of entire reefs to recover within 5-10 years if other stressors, such as pollution, are minimized. Coral reefs today suffer increasingly frequent stress events (Hughes et al., 2018). A recent study shows that hurricanes in the Gulf of Mexico are expected to increase in frequency and intensity, leading to increased flooding and runoff from coastal regions
(Marsooli et al., 2019). Our findings indicate that floodwaters following storms can trigger sub-lethal stress in corals, even when salinities remain fairly high; these impacts should be monitored and considered when assessing the cumulative threats to reef health.

\section{CONCLUSION}

Though the observed corals survived the effects of Hurricane Harvey in the summer of 2017, storm-driven flooding from the Tax Day Flood in Houston, TX, United States on this reef the previous summer caused a highly localized die-off event of corals and other marine invertebrates (Johnston et al., 2019; Kealoha, 2019). These events emphasize the urgency to closely monitor the health of coral reefs subjected to multiple anthropogenic threats of increasing severity. Experimental evidence demonstrates that osmotic challenges more extreme than those observed in the FGB following Harvey can cause coral mortality and compromise photosynthetic function of their algal symbionts (Kerswell and Jones, 2003; Downs et al., 2009). However, our genomewide gene expression analysis of two coral species and their associated symbionts in the FGB following Hurricane Harvey suggests that these endangered animals suffered sub-lethal stress, specifically related to redox state and mitochondrial function, which may compromise their ability to withstand subsequent stress (Adjeroud et al., 2009). Although these corals were able to recover following Harvey, they are likely to experience storm runoff associated stress in the future as tropical storms increase in frequency and intensity. Monitoring coral health in the Gulf of Mexico is especially urgent considering the massive ongoing coral declines throughout the Caribbean (Rippe et al., 2019). Healthy coral colonies at the FGB sustain the local ecosystem and produce larvae that disperse throughout the Caribbean (Davies et al., 2017), which may help restore those devastated reefs. Establishing baseline physiological measurements, including global gene expression, for this important group of corals can help managers disentangle normal seasonal fluctuations from sub-lethal stress events that may contribute to future mortality events.

\section{DATA AVAILABILITY STATEMENT}

The datasets generated for this study can be found in the National Center for Biotechnology Information Short Read Archive under accession number PRJNA552981.

\section{AUTHOR CONTRIBUTIONS}

RW analyzed gene expression and wrote the manuscript. SD designed the experiment and contributed to the manuscript. AC contributed to the experimental design, collected the samples, and contributed to the manuscript. LQ prepared the gene expression libraries and contributed to the manuscript. LS-V and KS assisted in sample collection and contributed to the manuscript. 


\section{FUNDING}

This work was funded by NSF awards OCE-1800904 to SD and OCE-1800914 to AC, OCE-1800905 to LS-V, and OCE-1800913 to KS, and stipend support for LQ was provided by a LINK Award through Brown University.

\section{ACKNOWLEDGMENTS}

September 2017 samples were collected on the R/V Manta and October 2017 samples were collected aboard the R/V Point Sur. We acknowledge the crew from these vessels and members of the NOAA FGB office. The authors particularly thank members of the science party during the cruises: Carsten Grupstra, Lauren

\section{REFERENCES}

Adjeroud, M., Michonneau, F., Edmunds, P. J., Chancerelle, Y., de Loma, T. L., Penin, L., et al. (2009). Recurrent disturbances, recovery trajectories, and resilience of coral assemblages on a South Central Pacific reef. Coral Reefs 28, 775-780. doi: 10.1007/s00338-009-0515-7

Aguilar, C., Raina, J.-B., Fôret, S., Hayward, D. C., Lapeyre, B., Bourne, D. G., et al. (2019). Transcriptomic analysis reveals protein homeostasis breakdown in the coral Acropora millepora during hypo-saline stress. BMC Genomics 20:148. doi: 10.1186/s12864-019-5527-2

Barshis, D. J., Ladner, J. T., Oliver, T. A., and Palumbi, S. R. (2014). Lineagespecific transcriptional profiles of Symbiodinium spp. unaltered by heat stress in a coral host. Mol. Biol. Evol. 31, 1343-1352. doi: 10.1093/molbev/ msul07

Barshis, D. J., Ladner, J. T., Oliver, T. A., Seneca, F. O., Traylor-Knowles, N., and Palumbi, S. R. (2013). Genomic basis for coral resilience to climate change. Proc. Natl. Acad. Sci. U.S.A. 110, 1387-1392. doi: 10.1073/pnas.1210224110

Baumgarten, S., Bayer, T., Aranda, M., Liew, Y. J., Carr, A., Micklem, G., et al. (2013). Integrating microRNA and mRNA expression profiling in Symbiodinium microadriaticum, a dinoflagellate symbiont of reef-building corals. BMC Genomics 14:704. doi: 10.1186/1471-2164-14-704

Benjamini, Y., and Hochberg, Y. (1995). Controlling the false discovery rate: a practical and powerful approach to multiple testing. J. R. Stat. Soc. Series B57, 289-300. doi: 10.1111/j.2517-6161.1995.tb02031.x

Berkelmans, R., Jones, A. M., and Schaffelke, B. (2012). Salinity thresholds of Acropora spp. on the great barrier reef. Coral Reefs 31, 1103-1110. doi: 10.1007/ s00338-012-0930-z

Bries, J. M., Debrot, A. O., and Meyer, D. L. (2004). Damage to the leeward reefs of curacao and bonaire, Netherlands antilles from a rare storm event: hurricane lenny, november 1999. Coral Reefs 23, 297-307.

Brown, B. E., Dunne, R. P., Ambarsari, I., Le Tissier, M. D. A., and Satapoomin, U. (1999). Seasonal fluctuations in environmental factors and variations in symbiotic algae and chlorophyll pigments in four Indo-Pacific coral species. Mar. Ecol. Prog. Ser. 191, 53-69. doi: 10.3354/meps19 1053

Carilli, J. E., Norris, R. D., Black, B. A., Walsh, S. M., and McField, M. (2009). Local stressors reduce coral resilience to bleaching. PLoS One 4:e6324. doi: 10.1371/journal.pone.0006324

Daniels, C., Baumgarten, S., Yum, L., Michell, C., Bayer, T., Arif, C., et al. (2015). Metatranscriptome analysis of the reef-building coral Orbicella faveolata indicates holobiont response to coral disease. Front. Mar. Sci. 2:62.

Davies, S. W., Marchetti, A., Ries, J. B., and Castillo, K. D. (2016). Thermal and pCO2 Stress elicit divergent transcriptomic responses in a resilient coral. Front. Mar. Sci. 3:112.

Davies, S. W., Ries, J. B., Marchetti, A., and Castillo, K. D. (2018). Symbiodinium functional diversity in the coral siderastrea siderea is influenced by thermal stress and reef environment, but not ocean acidification. Front. Mar. Sci. 5:150.
Howe-Kerr, Anna Knochel, and Jordan Sims (Rice University), Jason Sylvan, Shawn Doyle, Bryan Buckingham, and Miranda Hooper (Texas A\&M University), Michael Grimes (UHCL), Marissa Nuttall, John Embesi, and James MacMillan (NOAA), Jake Emmert and Kaitlin Buhler (Moody Gardens), Lauren Fuess (The University of Texas at Arlington) for field and logistical support, Emma Hickerson for facilitating collection permits, and Matthew Arnold for molecular work assistance.

\section{SUPPLEMENTARY MATERIAL}

The Supplementary Material for this article can be found online at: https://www.frontiersin.org/articles/10.3389/fmars. 2019.00672/full\#supplementary-material

Davies, S. W., Strader, M. E., Kool, J. T., Kenkel, C. D., and Matz, M. V. (2017). Modeled differences of coral life-history traits influence the refugium potential of a remote Caribbean reef. Coral Reefs 36, 913-925. doi: 10.1007/s00338-0171583-8

Dixon, G. B., Davies, S. W., Aglyamova, G. V., Meyer, E., Bay, L. K., and Matz, M. V. (2015). Genomic determinants of coral heat tolerance across latitudes. Science 348, 1460-1462. doi: 10.1126/science.1261224

Dixon, P. (2003). VEGAN, a package of $\mathrm{R}$ functions for community ecology. J. Veg. Sci. 14, 927-930. doi: 10.1111/j.1654-1103.2003.tb02 228. $\mathrm{x}$

Downs, C. A., Kramarsky-Winter, E., Woodley, C. M., Downs, A., Winters, G., Loya, Y., et al. (2009). Cellular pathology and histopathology of hypo-salinity exposure on the coral Stylophora pistillata. Sci. Total Environ. 407, 4838-4851. doi: 10.1016/j.scitotenv.2009.05.015

Du, J., Park, K., Dellapenna, T. M., and Clay, J. M. (2019). Dramatic hydrodynamic and sedimentary responses in Galveston Bay and adjacent inner shelf to Hurricane Harvey. Sci. Total Environ. 653, 554-564. doi: 10.1016/j.scitotenv. 2018.10.403

Edmunds, P. J. (2019). The demography of hurricane effects on two coral populations differing in dynamics. Ecosphere 10:e02836.

Gardner, L. B. (2008). Hypoxic inhibition of nonsense-mediated RNA decay regulates gene expression and the integrated stress response. Mol. Cell. Biol. 28, 3729-3741. doi: 10.1128/MCB.022 84-07

Gardner, T. A., Côté, I. M., Gill, J. A., Grant, A., and Watkinson, A. R. (2003). Long-term region-wide declines in Caribbean corals. Science 301, 958-960. doi: 10.1126/science. 1086050

Gardner, T. A., Cote, I. M., Gill, J. A., Grant, A., and Watkinson, A. R. (2005). Hurricanes and Caribbean coral reefs: impacts, recovery patterns, and role in long-term decline. Ecology 86, 174-184. doi: 10.1890/040141

Goreau, T. F. (1964). Mass Expulsion of Zooxanthellae from Jamaican Reef Communities after Hurricane Flora. Science 145, 383-386. doi: 10.1126/science. 145.3630 .383

Green, E. A., Davies, S. W., Matz, M. V., and Medina, M. (2014). Quantifying cryptic Symbiodinium diversity within Orbicella faveolata and Orbicella franksi at the flower garden banks. Gulf of Mexico. PeerJ 2, e386. doi: 10.7717/peer j.386

Hannon, G. (2010). Fastx-Toolkit. FASTQ/A Short-Reads Preprocessing Tools. Available at: http://hannonlab.cshl.edu/fastx_toolkit/ (accessed on October 2015).

Highsmith, R. C., Riggs, A. C., and D’Antonio, C. M. (1980). Survival of hurricanegenerated coral fragments and a disturbance model of reef calcification/growth rates. Oecologia 46, 322-329. doi: 10.1007/BF00346259

Hughes, T. P., Kerry, J. T., Baird, A. H., Connolly, S. R., Dietzel, A., Eakin, C. M., et al. (2018). Global warming transforms coral reef assemblages. Nature 556, 492-496. doi: 10.1038/s41586-018-0041-2 
Jin, Y. K., Lundgren, P., Lutz, A., Raina, J.-B., Howells, E. J., Paley, A. S., et al. (2016). Genetic markers for antioxidant capacity in a reef-building coral. Sci. Adv. 2:e1500842. doi: 10.1126/sciadv.1500842

Johnston, M. A., Embesi, J. A., Eckert, R. J., Nuttall, M. F., Hickerson, E. L., and Schmahl, G. P. (2016). Persistence of coral assemblages at east and west flower garden banks, gulf of Mexico. Coral Reefs 35, 821-826. doi: 10.1007/s00338016-1452-X

Johnston, M. A., Nuttall, M. F., Eckert, R. J., Blakeway, R. D., Sterne, T. K., Hickerson, E. L., et al. (2019). Localized coral reef mortality event at east flower garden bank, gulf of Mexico. Bull. Mar. Sci. 95, 239-250. doi: 10.5343/bms. 2018.0057

Jokiel, P. L., Hunter, C. L., Taguchi, S., and Watarai, L. (1993). Ecological impact of a fresh-water "reef kill" in Kaneohe Bay. Oahu, Hawaii. Coral Reefs 12, 177-184. doi: $10.1007 /$ bf00334477

Jonsson, S., Andersson, A., Nilsson, M. B., Skyllberg, U., Lundberg, E., Schaefer, J. K., et al. (2017). Terrestrial discharges mediate trophic shifts and enhance methylmercury accumulation in estuarine biota. Sci. Adv. 3, e1601239. doi: 10.1126/sciadv.1601239

Kauffmann, A., Gentleman, R., and Huber, W. (2009). ArrayQualityMetrics-a bioconductor package for quality assessment of microarray data. Bioinformatics 25, 415-416. doi: 10.1093/bioinformatics/btn647

Kealoha, A. K. (2019). Coral Reef Ecosystem Health in Response to Climate Change and Environmental Stressors. Doctoral Dissertation. Texas: Texas A\&M University, College Station.

Kerswell, A. P., and Jones, R. J. (2003). Effects of hypo-osmosis on the coral Stylophora pistillata: nature and cause of "low-salinity bleaching.". Mar. Ecol. Progr. Ser. 253, 145-154. doi: 10.3354/meps253145

Kohno, Y., Satoh, H., Iguchi, A., and Nagai, H. (2009). Characterization of a new hemolytic protein toxin from the sea anemone Anthopleura asiatica. Fish. Sci. 75, 1049-1054. doi: 10.1007/s12562-009-0112-2

Kolde, R. (2012). Pheatmap: pretty heatmaps. R Packag. Version 61, 617.

LaJeunesse, T. C., Parkinson, J. E., Gabrielson, P. W., Jeong, H. J., Reimer, J. D., Voolstra, C. R., et al. (2018). Systematic revision of symbiodiniaceae highlights the antiquity and diversity of coral endosymbionts. Curr. Biol 28, 2570.e62580.e6. doi: 10.1016/j.cub.2018.07.008

Langmead, B., and Salzberg, S. L. (2012). Fast gapped-read alignment with Bowtie 2. Nat. Methods 9, 357-359. doi: 10.1038/nmeth.1923

Lefebure, R., Degerman, R., Andersson, A., Larsson, S., Eriksson, L.-O., Båmstedt, U., et al. (2013). Impacts of elevated terrestrial nutrient loads and temperature on pelagic food-web efficiency and fish production. Glob. Chang. Biol. 19, 1358-1372. doi: $10.1111 /$ gcb.12134

Leggat, W., Seneca, F., Wasmund, K., Ukani, L., Yellowlees, D., and Ainsworth, T. D. (2011). Differential responses of the coral host and their algal symbiont to thermal stress. PLoS One 6:e26687. doi: 10.1371/journal.pone.002 6687

Liñán-Cabello, M. A., Olivos-Ortiz, A., Quijano-Scheggia, S., Muñiz Anguiano, D., Reséndiz-Flores, M. L., and Ortega-Ortíz, C. D. (2016). Effects of terrestrial runoff on the coral communities in santiago bay. colima, mexican Pacific Coast. Rev. Biol. Trop. 64, 1185-1200.

Lopes, A. R., Faleiro, F., Rosa, I. C., Pimentel, M. S., Trubenbach, K., Repolho, T., et al. (2018). Physiological resilience of a temperate soft coral to ocean warming and acidification. Cell Stress Chaperones 23, 1093-1100. doi: 10.1007/s12192018-0919-9

Love, M. I., Huber, W., and Anders, S. (2014). Moderated Estimation of Fold Change and Dispersion for RNA-Seq Data With DESeq2 biorxiv. [preprint]. doi: 10.1101/002832

Maboloc, E. A., Puzon, J. J. M., and Villanueva, R. D. (2015). Stress responses of zooxanthellae in juvenile Tridacna gigas (Bivalvia. Cardiidae) exposed to reduced salinity. Hydrobiologia 762, 103-112. doi: 10.1007/s10750-0152341-y

Mansfield, K. M., Cleves, P. A., Van Vlack, E., Kriefall, N. G., Benson, B. E., Camacho, D. J., et al. (2019). Varied Effects of Algal Symbionts on Transcription Factor NF-кB in a Sea Anemone and a Coral: Possible Roles in Symbiosis and Thermotolerance Biorxiv. [preprint]. doi: 10.1101/640177

Manzello, D., Enochs, I., Musielewicz, S., Carlton, R., and Gledhill, D. (2013). Tropical cyclones cause $\mathrm{CaCO} 3$ undersaturation of coral reef seawater in a high-CO2 world. J. Geophys. Res. C: Oceans 118, 5312-5321. doi: 10.1002/jgrc. 20378
Manzello, D. P., Matz, M. V., Enochs, I. C., Valentino, L., Carlton, R. D., Kolodziej, G., et al. (2018). Role of host genetics and heat-tolerant algal symbionts in sustaining populations of the endangered coral Orbicella faveolata in the Florida keys with ocean warming. Glob. Chang. Biol. 25, 1016-1031. doi: 10.1111/gcb. 14545

Marsooli, R., Lin, N., Emanuel, K., and Feng, K. (2019). Climate change exacerbates hurricane flood hazards along US Atlantic and Gulf Coasts in spatially varying patterns. Nat. Commun. 10:3785. doi: 10.1038/s41467-019-11755-z

Meyer, E., Aglyamova, G. V., and Matz, M. V. (2011). Profiling gene expression responses of coral larvae (Acropora millepora) to elevated temperature and settlement inducers using a novel RNA-Seq procedure. Mol. Ecol. 20, 35993616. doi: 10.1111/j.1365-294X.2011.05205.x

Nelson, H. R., and Altieri, A. H. (2019). Oxygen: the universal currency on coral reefs. Coral Reefs 38, 177-198. doi: 10.1007/s00338-019-01 765-0

Nussenblatt, R. B., Mittal, K. K., Ryan, S., Green, W. R., and Maumenee, A. E. (1982). Birdshot retinochoroidopathy associated with HLA-A29 antigen and immune responsiveness to retinal S-antigen. Am. J. Ophthalmol. 94, 147-158. doi: 10.1016/0002-9394(82)90069-1

Parkinson, J. E., Baumgarten, S., Michell, C. T., Baums, I. B., LaJeunesse, T. C., and Voolstra, C. R. (2016). Gene expression variation resolves species and individual strains among coral-associated dinoflagellates within the genus Symbiodinium. Genome Biol. Evol. 8, 665-680. doi: 10.1093/gbe/ev w019

Pastor, M. M., Proft, M., and Pascual-Ahuir, A. (2009). Mitochondrial function is an inducible determinant of osmotic stress adaptation in yeast. J. Biol. Chem. 284, 30307-30317. doi: 10.1074/jbc.M109.050682

Pengsakun, S., Yeemin, T., Sutthacheep, M., Samsuvan, W., Klinthong, W., and Chamchoy, C. (2019). Monitoring of coral communities in the inner Gulf of Thailand influenced by the elevated seawater temperature and flooding. Acta Oceanol. Sin. 38, 102-111. doi: 10.1007/s13131-0191376-8

Pinzon, J. H., Kamel, B., Burge, C. A., Harvell, C. D., Medina, M., Weil, E., et al. (2015). Whole transcriptome analysis reveals changes in expression of immunerelated genes during and after bleaching in a reef-building coral. $R$. Soc. Open Sci. 2, 140214-140214. doi: 10.1098/rsos.140214

R Core Team, (2017). R: A Language and Environment for Statistical Computing. $R$ Foundation for Statistical Computing. Vienna: R Core Team.

Rippe, J. P., Kriefall, N. G., Davies, S. W., and Castillo, K. D. (2019). Differential disease incidence and mortality of inner and outer reef corals of the upper florida keys in association with a white syndrome outbreak. Bull. Mar. Sci. 95, 305-316. doi: 10.5343/bms.2018.0034

Santos, R. S., and LaJeunesse, T. C. (2006). Searchable Database of Symbiodinium Diversity-Geographic and Ecological Diversity (SD2-GED). Auburn, AL: Auburn University.

Shaul, O. (2015). Unique aspects of plant nonsense-mediated mRNA decay. Trends Plant Sci. 20, 767-779. doi: 10.1016/j.tplants.2015.08.011

Shultz, J. M., and Galea, S. (2017). Mitigating the mental and physical health consequences of Hurricane Harvey. JAMA 318, 1437-1438.

Takahashi, S., Yoshioka-Nishimura, M., Nanba, D., and Badger, M. R. (2013). Thermal acclimation of the symbiotic alga Symbiodinium spp. alleviates photobleaching under heat stress. Plant Physiol. 161, 477-485. doi: 10.1104/pp. 112.207480

Titlyanov, E. A., Tsukahara, J., Titlyanova, T. V., Leletkin, V. A., Van Woesik, R., and Yamazato, K. (2000). Zooxanthellae population density and physiological state of the coral Stylophora pistillata during starvation and osmotic shock. Symbiosis 28, 303-322.

van Oldenborgh, G. J., van der Wiel, K., Sebastian, A., Singh, R., Arrighi, J., Otto, F., et al. (2017). Attribution of extreme rainfall from Hurricane Harvey, August 2017. Environ. Res. Lett. 12:124009. doi: 10.1088/1748-9326/aa 9ef2

Weil, E., and Knowlton, N. (1994). A multi-character analysis of the caribbean coral montastraea annularis (Ellis and Solander, 1786) and its two sibling species, M. Faveolata (Ellis and Solander, 1786) and M. Franksi (Gregory, 1895). Bull. Mar. Sci. 55, 151-175.

Woodley, J. D., Chornesky, E. A., Clifford, P. A., Jackson, J. B., Kaufman, L. S., Knowlton, N., et al. (1981). Hurricane allen's impact on jamaican coral reefs. Science 214, 749-755. 
Wright, R. M., Aglyamova, G. V., Meyer, E., and Matz, M. V. (2015). Gene expression associated with white syndromes in a reef building coral, Acropora hyacinthus. BMC Genomics 16:371. doi: 10.1186/s12864-015-1540-2

Wright, R. M., Kenkel, C. D., Dunn, C. E., Shilling, E. N., Bay, L. K., and Matz, M. V. (2017). Intraspecific differences in molecular stress responses and coral pathobiome contribute to mortality under bacterial challenge in Acropora millepora. Sci. Rep. 7:2609. doi: 10.1038/s41598-017-02685-1

Yuyama, I., Ishikawa, M., Nozawa, M., Yoshida, M.-A., and Ikeo, K. (2018). Transcriptomic changes with increasing algal symbiont reveal the detailed process underlying establishment of coral-algal symbiosis. Sci. Rep. 8:16802. doi: $10.1038 / s 41598-018-34575-5$
Conflict of Interest: The authors declare that the research was conducted in the absence of any commercial or financial relationships that could be construed as a potential conflict of interest.

Copyright (c) 2019 Wright, Correa, Quigley, Santiago-Vázquez, Shamberger and Davies. This is an open-access article distributed under the terms of the Creative Commons Attribution License (CC BY). The use, distribution or reproduction in other forums is permitted, provided the original author(s) and the copyright owner(s) are credited and that the original publication in this journal is cited, in accordance with accepted academic practice. No use, distribution or reproduction is permitted which does not comply with these terms. 